\title{
Discursos históricos sobre la independencia del Perú en los textos escolares: Gustavo Pons Muzzo, Pablo Macera y Editorial Santillana
}

Recibido: 15/08/2021

Aprobado: 11/11/2021

\author{
EDDY WALTER ROMERO MEZA \\ Universidad Peruana Cayetano Heredia (UPCH) \\ eddy.romero.m@upch.pe \\ https://orcid.org/0000-0002-1247-4903
}

\section{RESUMEN}

El presente artículo buscará aproximarse a los discursos históricos sobre la independencia del Perú presentes en tres textos escolares: Historia del Perú. Época de la emancipación (1957) de Gustavo Pons Muzzo, Historia del Perú. Independencia y república (1986) de Pablo Macera, y Ciencias Sociales 3 (2020) de Editorial Santillana. Para ello, se analizará las características de los distintos autores (contextos, formación historiográfica, lugares de enunciación, etc.), sus interpretaciones históricas y las diversas representaciones que proponen en los manuales escolares. También se analizará algunos elementos didácticos presentes en los textos escolares y las representaciones gráficas que lo acompañan, para tener una visión general de los manuales de historia diseñados por los autores mencionados. Se distingue la producción de los textos escolares dentro de las corrientes de la historia nacional criolla (Pons Muzzo), la historia nacional crítica (Pablo Macera) y la historia académica actual (Editorial Santillana). En el trabajo se destaca, además, la importancia de examinar los textos escolares más allá de la imagen de objetos pedagógicos neutros o desideologizados.

Palabras clave: textos escolares, historia del Perú, independencia, discurso histórico, representaciones

\section{Historical Discourses about the Peruvian Independence in school textbooks: Gustavo Pons Muzzo, Pablo Macera and Editorial Santillana}

\begin{abstract}
This article will seek to approach the historical discourses about the Peruvian Independence as presented in three school textbooks: History of Peru. Time of emancipation (1957) by Gustavo Pons Muzzo, History of Peru. Independence and Republic (1986) by Pablo Macera, and Social Sciences 3 (2020) by Editorial Santillana. To do so, the characteristics of the different authors will be analyzed (context, historiographic training, place of enunciation, etc.), their historical interpretations and the various representations they propose in school manuals. The analysis will also include some didactic elements present in school textbooks and their supplementary illustrations, in order to have an overview of the history manuals designed by the aforementioned authors. The production of school textbooks is divided within the currents of the national Creole history (Pons Muzzo), the critical national history (Pablo Macera) and the current academic history (Editorial Santillana). The work also highlights the importance of examining school textbooks beyond the image of neutral or de-ideologized pedagogical objects.
\end{abstract}

Keywords: school textbooks, Peruvian history, independence, historical narrative, representations 


\begin{abstract}
No nos engañemos: la imagen que tenemos de otros pueblos, y hasta de nosotros mismos, está asociada a la Historia tal como se nos contó cuando éramos niños...

Controlar el pasado ayuda a dominar el presente, a legitimar dominaciones e impugnaciones... la historia que se cuenta a los niños, o a los adultos, permite a la vez conocer la identidad y el status de esta a través del tiempo... Benedetto Croce escribía a principios de siglo que la historia plantea los problemas de su tiempo más que los de la época que es objeto de su estudio.

Marc Ferro, Cómo se cuenta la historia a los niños en el mundo entero (1981)
\end{abstract}

$\mathrm{H}$

n las últimas décadas, los estudios sobre los textos escolares han adquirido mayor importancia, convirtiéndose en una especialidad de la disciplina histórica y la educación. Destacan los trabajos impulsados por el Instituto Eckert (Alemania, 1975), el Centro Manes (España, 1992), así como por diversos autores provenientes de distintas disciplinas de estudio. Estos autores han destacado la importancia de los textos escolares, tanto desde su dimensión pedagógica (curricular-didáctico) como de su carácter ideológico o político, sobre todo en el caso de los textos de Historia o Ciencias Sociales.

El curso de Historia en las escuelas nace en contexto de la formación de los Estado-nación modernos en el siglo XIX (Prats 2001), los cuales exigieron relatos legitimadores o narrativas orientadas a la formación de una conciencia e identidad nacional: «Durante lo que convencionalmente conocemos por edad moderna, se prefiguran usos de la educación histórica que constituyen, en nuestra opinión, el sustrato más sólido a partir del que se va construyendo e inventando, ya en el siglo XIX, el código disciplinar de la Historia» (Cuesta 1997, 18).

Mario Carretero $(2005,2006)$ ha explicado que dos tipos de lógicas se han articulado en la enseñanza escolar de la historia, desde el origen de los Estados liberales hasta mediados del siglo XX: la racionalidad crítica de la Ilustración y la emotividad identitaria del Romanticismo. Ambas «han constituido la impronta de la historia escolar y definen aún hoy sus objetivos como cognitivos, destinados a la formación del conocimiento disciplinar, y sociales o identitarios, dirigidos a la formación de la identidad nacional» (Carretero 2006, p. 13). En ese sentido, Gómez y Miralles (2017) explican cómo la racionalidad crítica de la Ilustración se traduce en la enseñanza de la historia a la necesidad de educar en valores cívicos y sociales, así como en aspectos cognitivos de la disciplina histórica, como la racionalidad científica. En cambio, la emotividad identitaria del Romanticismo se expresa en la enseñanza escolar de la historia, en la necesidad de transmitir las hazañas patrias que afirmen las identidades nacionales, contribuyendo a la construcción de una memoria colectiva (Gómez y Miralles 2017, 9-10). 
Influidos por el racionalismo de la Ilustración y la exaltación identitaria del Romanticismo, los textos o manuales escolares de historia fueron los objetos-medios para promover una educación cívica o ciudadana, instalando una serie de valores y representaciones del «nosotros» (origen común, figuras representativas, fracasos y éxitos comunes, etc.). Los proyectos nacionales enfatizaron la necesidad de cohesionar o unir a la sociedad a través de la educación. Sin embargo, a pesar de existir un discurso oficial, ${ }^{1}$ las ideas de nación podían variar y hasta contraponerse. Pensar la nación desde las élites de la capital resultaba distinto a hacerlo desde sectores populares urbano o rurales de la sierra sur (Cusco o Puno, por ejemplo). Durante la república, la nación criolla-mestiza, tuvo su contraparte en la nación indígena-mestiza, existiendo elementos comunes y también reivindicaciones distintas.

Los textos escolares dan cuenta de las intencionalidades o propuestas para representar o pensar la historia y el presente del país, pero es muy distinto conocer su verdadero impacto, como su recepción o apropiación por maestros y estudiantes. ${ }^{2}$ Las formas como se emplearon los textos en la escuela, son diversas; desde un apego estricto a su contenido, a su uso parcial y/o referencial, o su posible cuestionamiento. Al respecto Tulio Ramírez (2003) ha señalado:

Presumir que los maestros utilizan los textos escolares de la misma manera no es
más que una ilusión producto del desconocimiento del quehacer diario de los docen-
tes. Pero no bastaría con lograr una taxonomía sobre el uso de este recurso didácti-
co, detrás de cada uso es necesario detectar aquellas variables que dan sentido a ta-
les actuaciones, algunas de ellas de carácter personal, otras de carácter académico,
institucional, pedagógico, ideológico, religioso o político, que podrían servir para
explicar la conducta de los maestros con respecto al texto escolar (Ramírez, 2003).

De igual manera, el uso de los textos escolares por los mismos estudiantes también debe ser examinado desde las múltiples experiencias o contextos. Así, mientras en sectores sociales de clase alta y media el acceso a los libros de texto pudo ser masivo, en localidades pobres, el acceso a los libros siempre

1 «En el caso de la enseñanza de la historia, es indudable que los libros de texto han transmitido, general, la versión histórica oficial que las sociedades tienen de su pasado» (López y Carretero 2004, 154).

2 «[...] un campo fundamental en el estudio de los manuales escolares es el que presenta el proceso educativo como una experiencia en la que intervienen el manual, el estudiante, el profesor, la familia, los medios de comunicación, etcétera. De hecho, es absurdo pretender que el conocimiento sobre el pasado de un estudiante recién egresado de la secundaria resulte similar a los contenidos de los manuales que utilizó durante su escolaridad» (Parodi 2019, 55). 
fue restringido, a veces solo limitado al docente de aula. ${ }^{3}$ Instituciones públicas y privadas podían dar uso diferenciado a los libros, incluyendo los miles de colegios religiosos. Los libros escolares son mediadores entre el currículo y la enseñanza final en las aulas; así como los docentes son los mediadores entre los estudiantes y los contenidos de los libros escolares, sobre todo en aquellos contextos donde su acceso fue limitado.

Los libros de historia y los textos escolares a veces dicen mucho más de sus autores que de sus temas de estudio. Nos hablan de sus posturas historiográficas, reflejan sus valores e ideas políticas, sus preocupaciones y propuestas. La representación histórica está definida por la selección de contenidos, las presencias y las ausencias. En el pasado la promoción de una historia patria, principalmente política (presidentes y héroes militares), y hoy una historia con matices más sociales y culturales en sus contenidos. Los textos escolares de historia transmiten diferentes representaciones sociales: género, raza, clase, cultura, etc. Son espacios de memoria y generadores de memorias; además de reflejar los cambios de los proyectos curriculares y los avances historiográficos. En los manuales escolares se observan cambios y permanencias, negociaciones y tensiones sociales-políticas, a pesar de su aparente asepsia o neutralidad pedagógica. Cabría acá destacar lo señalado por Nilson Ibagón $(2014,140)$ :

[...] es fundamental tener presente el contexto espacio-temporal en el que se produce y utiliza determinado texto escolar, factor analítico que nos introduce en su dimensión como vector de memoria. Según Benito Escolano (2001), en el manual escolar se condensan simultáneamente métodos pedagógicos y valores sociales, razón por la cual se constituye en un espejo que refleja desde su materialidad los rasgos de la sociedad que los produce, la cultura en la que se inserta y los marcos pedagógicos que regulan su uso. En otras palabras, el libro de texto analíticamente permite definir trazos temporales que dan simultáneamente cuenta de su pasado, ubicando la producción, el contenido y el uso, y también de la relación de éste con las configuraciones de forma y de fondo con las cuales se sitúa en la actualidad.

3 «[...] la formación y capacitación de los maestros no parece haber avanzado en el Perú, a la par con la transformación del texto escolar. Así, es muy probable que la carencia de una formación y capacitación sólidas en el uso de textos provoque una incompatibilidad entre lo que estos materiales pretenden y lo que el profesor sabe hacer con ellos. Es factible que dicha incompatibilidad ocasione que los textos simplemente no se usen, o que sean usados de forma limitada, lo cual crea serios cuestionamientos sobre la idoneidad de los procesos de dotación de textos escolares en el Perú, con la inversión que ellos significan» (De Belaunde, Eguren y González 2005, 35). 
Los libros escolares, finalmente, deben ser estudiados también desde su lenguaje. Predomina el discurso de autoridad del autor-especialista, y el uso del plural masculino. Antaño discursos «cerrados» (basado en sentencias); en otros, lenguaje académico-neutro (distante frente al lector); y a veces el uso de mensajes infantilizantes (simplificaciones o poca densidad analítica). Eran raros los textos de historia basados en la pedagogía de la pregunta, cierta dialéctica o el diálogo mediante interrogantes críticas, sembradas a lo largo del manual; hoy son más frecuentes, pero no dejan de tener limitaciones.

\section{Gustavo Pons Muzzo y el discurso histórico sobre la independencia en los textos escolares}

Gustavo Pons Muzzo (1922-2008), nacido en Tacna, pero afincado en Lima desde muy temprano, se graduó en la Universidad San Marcos, y llegó a ser discípulo y asistente de Jorge Basadre. Fue autor de los textos oficiales de Historia del Perú para los cinco grados de educación secundaria (reeditados entre 1950 y 1990). Entre su obra destacan también Educación para los jóvenes peruanos; hacia una doctrina de la educación nacional (1953), Las fronteras del Perú (1962), Historia del conflicto entre el Perú y España, 1864-1866 (1966), Politica educativa del Estado peruano (1966), El gobierno protectoral del Libertador Generalísimo José de San Martín (1971), La Expedición Libertadora (3 volúmenes, 1971), Símbolos de la patria (1974), El coronel Francisco Bolognesi y el expansionismo chileno (1987), Estudio histórico sobre el Protocolo de Río de Janeiro (1994) y Breve reseña histórica de los límites fronterizos Perú-Ecuador (1995).

El discurso histórico de Gustavo Pons Muzzo puede ubicarse dentro de lo que Manuel Burga $(2005)^{4}$ ha denominado «versión criolla de la historia nacional», en la cual destacan también autores como Riva Agüero, Porras

4 Sobre los discursos históricos, Manuel Burga $(2005,64)$ ha señalado: «Eric J. Hobsbawm, últimamente muy interesado en discutir la historia y el significado de la nación y de los nacionalismos, suele decir que la conciencia nacional - de alguna manera - se elabora desde la historia de una nación, su memoria colectiva, y puesto que los historiadores son sus constructores de oficio, estos — lógicamente — están directamente implicados en los procesos de construcción de las naciones modernas. Entonces, sin duda alguna, al analizar las 'historias' que tenemos y que escribimos podemos acercarnos a los problemas relacionados a la emergencia, desarrollo y madurez de la conciencia nacional en el Perú. Esta conciencia, como ha sucedido en casi todas partes, ha sido ampliamente influenciada y aun manipulada por los grupos dominantes a través del uso y abuso de la historia o de la elaboración de discursos históricos dirigidos a legalizarlos o legitimarlos como tales». 
Barrenechea, Jorge Basadre y Luis Alberto Sánchez. «Este discurso encuentra numerosos aspectos negativos en el sistema colonial hispano, elogia la historia indígena, promueve un Perú mestizo y enfatiza la inevitabilidad absoluta de la aplicación de la cultura, ciencia y tecnología occidentales en el Perú» (Burga 2005, 64). Pons Muzzo propone una historia patria, pero no patriotera, basada en un nacionalismo criollo-mestizo, que introduce críticas breves sobre el desarrollo histórico-social del país. El autor puede ser inscrito dentro de la historiografía conservadora peruana, junto con Carlos Wiesse, José de la Riva Agüero, Raúl Porras Barrenechea, José Agustín de la Puente Candamo, entre otros.

Los discursos históricos de los autores no son fijos, experimentan cambios, ajustes o reacomodos, como ha explicado el historiador de las ideas Elías Palti. Sin embargo, pueden mantenerse algunas ideas en el tiempo, y estas se asocian a discursos sociales mayores. En el caso de Pons Muzzo, es clara su adhesión al discurso nacional-criollo de inicios del siglo XX; cultiva una historia afirmativa de lo peruano, entendido esta como una colectividad mestiza y occidentalizada. Aunque introduce críticas, estas se orientan a una visión reformista, antes que transformativa de la política y la sociedad. El nacionalismo en la obra de Pons Muzzo puede ser leído en clave positiva, pero también en clave crítica. ${ }^{5}$

Para el autor, la emancipación resulta la gesta fundadora y la adquisición de la madurez de la peruanidad; el Perú, además, tiene un rol protagónico en la región, como su historia lo demuestra (Imperio inca y centro del poder colonial). La independencia de América, culminada en las pampas de Ayacucho, constituye uno de los eventos más importantes de la historia moderna. Escribe Pons Muzzo (1957, prefacio):

Al terminar la guerra emancipadora en 1824, el mundo contempla el maravilloso espectáculo de ver surgir en el Continente llamado «Las Indias» o «Nuevo Mundo» la más armoniosa constelación de naciones independientes. Con razón

5 La investigadora Teresa Chávez $(2006,20)$ ha señalado que «Los dos historiadores del siglo XX preocupados por la enseñanza secundaria, Jorge Guillermo Leguía y Gustavo Pons Muzzo, han marcado huella en la historiografia escolar peruana. Cada uno en su época, ambos trataron de entregar en sus textos escolares, elementos formativos para incentivar la identidad nacional». Por su parte, la historiadora Cecilia Israel $(2009,26)$ discute esta afirmación, al examinar el capítulo que Pons Muzzo dedicó a la guerra con Chile en su texto escolar de cuarto de secundaria, considerando que «está plagado de adjetivos despectivos y subjetivos, que lo único que crean en el estudiante es una conciencia antichilena». Sobre esto, valdría recordar que existe el nacionalismo negativo, que se promueve en la contraposición a un «otro». En el caso peruano, el nacionalismo criollo se afianzó en el antagonismo al rival chileno (país invasor y amenaza presente). 
ha sido llamada la guerra Emancipadora de América española «el gigantesco acontecimiento del siglo XIX».

Pons Muzzo sostiene que la nación peruana es una realidad temprana. Una proto-nacionalidad surgida en tiempos coloniales, y que toma forma final con la emancipación. El historiador piensa sobre todo en la figura del crio1lo, quien se aleja de la metrópoli española y asume autonomía política, pero también psicológica. La patria peruana es una realidad indiscutible, aunque mayorías indígenas tuvieran poca conciencia de ella, en las primeras décadas del siglo XIX. Agrega Pons Muzzo (1957, 16-17):

Durante los tiempos coloniales se fueron formando la nación peruana y las demás naciones americanas. Junto con el proceso de formación de la nación peruana se fue formando la conciencia nacional, en los que se creían peruanos por haber nacido en esta tierra. Esta conciencia nacional no existió al principio de la colonia, pero sí al fin de la misma, porque entonces la nación peruana ya estaba formada. En el siglo XVIII el Perú ya existía. La Patria era entonces una realidad. Las batallas de la guerra emancipadora se dieron en nombre de la libertad y de la Patria.

Mientras Manuel González Prada afirmaba en Horas de lucha $(1908)^{6}$ que la verdadera nación peruana estaba en los Andes (la cual, los criollos ignoran o desprecian), los intelectuales de la capital promovían la idea de una nación mestiza ya conformada, capaz de superar duras pruebas, como la guerra del Pacífico. Asimilar a los pueblos alejados de la civilización era la tarea pendiente de la república. Mientras la historiografía más crítica señalaba que la nación peruana estaba todavía formándose, y que las divisiones todavía nos acompañaban, la historiografía más conservadora presentaba un país unificado y con un claro proyecto nacional, tras la guerra con Chile.

Pons Muzzo elaboró numerosos textos escolares de difusión nacional, expresando el discurso oficial desde la década de los cincuenta. Sus libros se caracterizaron por un lenguaje parco, con valoración mesurada de los sucesos históricos y la adhesión a las tesis de la nación mestiza defendida por

6 «No forman el Perú, las agrupaciones de criollos y extranjeros que habitan la faja de tierra situada entre el Pacífico y los andes; la nación está formada por la muchedumbre de indios discriminados en la banda oriental de la cordillera» (González Prada, 1908). 
intelectuales como Víctor Andrés Belaunde. Al respecto, señala el sociólogo Gonzalo Portocarrero $(1989,92)$ :

Tanto en Wiesse como en Pons Muzzo la crítica al orden colonial está atempe-
rada por la consideración de que el hecho central de la colonia no fue la domi-
nación y el enfrentamiento entre indios y españoles, sino la transculturación, la
formación de la nacionalidad peruana. Es apenas con los textos de Pablo Macera
que se da la ruptura que hemos indicado. El Perú deja de ser visto como una esen-
cia para ser imaginado como una construcción histórica precaria e incompleta,
pero antigua y poderosa.

En el prefacio de su libro Historia del Perú. Época de la emancipación (1957), Pons Muzzo declara que el curso de historia del Perú debe ser el que más contribuya a la formación de la conciencia nacional, haciendo sentir en el educando la emoción por el Perú. Pons Muzzo (1957) señala además que «La historia del Perú es una historia ilustre. Así lo demuestra un imparcial conocimiento que de ella hoy se tiene por el trabajo abnegado de los modernos historiadores, que, al margen de doctrinas extremistas (indigenismo, hispanismo, etc.), hurgan con carácter científico en los secretos de nuestra historia». El autor asume un particular discurso peruanista, el cual toma (aparente) distancia del pro-indigenismo y el pro-hispanismo; sin embargo, este discurso peruanista está basado en la conservadora ideología del mestizaje, la cual se caracteriza por ser desindigenizadora y occidentalizadora (Vom Hau 2009; Romero 2021).

Pons Muzzo (1957) advierte además en su prefacio que, aunque desarrolla todo el programa oficial, no lo hará de forma exhaustiva, pues «ello nos llevaría otra vez a la antigua enseñanza de la historia considerada como un conjunto de datos, que no hacían sino fatigar la memoria del estudiante en vez de adiestrar su inteligencia, haciéndole aprender datos aislados en vez de comprender su historia». Indica también que se prescindirá de incluir cuadros sinópticos al final de cada lección, que considera que es labor del maestro en el aula. Considera, finalmente, que los docentes deben hacer del estudiante «un elemento activo de la enseñanza» y no debe «reducirlo al papel de mero espectador».

Debe recordarse que Pons Muzzo fue docente en grandes unidades escolares de la capital, además del colegio militar Leoncio Prado. Se trata de un reconocido maestro de vocación indiscutible. Sin embargo, a pesar de su 
advertencia sobre el memorismo en las aulas, este fue el paradigma que predominaba en la enseñanza escolar en los cincuenta. El mismo Pons Muzzo presenta ejercicios o actividades de tipo memorístico en el libro que examinamos, aunque ocasionalmente incorpora preguntas que trascienden este. Algunos ejemplos de actividades los observamos en la página 157 («Haga una lista de los principales integrantes del Congreso Constituyente y de las libertades que proclamó la Constitución de 1823») y la página 197 («Trabajo práctico. 1. Dibuje un mapa de América colonial española conforme el modelo de la pág. 15 y trace en él la marcha de la Corriente Libertadora del sur desde su partida de Mendoza, y la marcha de la Corriente Libertadora del Norte, desde los llanos del Orinoco, señalando las batallas que tuvieron lugar por ambas corrientes libertadoras en su avance hacia el Perú hasta la batalla de Ayacucho. 2. Haga una lista en su cuaderno de los principales acontecimientos que tuvieron lugar desde que Bolívar llegó a la Guayana Venezolana en 1816 hasta que llegó triunfante al Alto Perú en 1825. 3. Haga un mapa de la batalla de Junín y otro de la batalla de Ayacucho»). Finalmente, en la página 225, se observa una actividad relacionada con los símbolos patrios («Trabajo práctico: Dibuje en su cuaderno, la bandera y el escudo nacional, dados por San Martín en Pisco; la bandera reformada por Torre Tagle, y la bandera, el escudo y el estandarte dados por el Congreso de 1823, empleando los colores de Ley»). Posteriormente, en el libro dedicado a cuarto de secundaria, Pons Muzzo enfatizará en el conocimiento y elaboración de los mapas de las fronteras del Perú. Cabría recordar que Pons Muzzo fue un historiador de los límites del Perú, y vivió en una época de conflictos por la definición de las fronteras nacionales.

En la portada del libro de Pons Muzzo, se aprecian las corrientes libertadoras del norte y el sur. Cabe destacar que, en los programas curriculares de los cincuenta, durante el tercer grado de secundaria, los estudiantes se concentraban solo en el periodo histórico de la emancipación y los inicios de la república. En cambio, en los programas posteriores, los estudiantes abarcarán la independencia y la república del siglo XIX. La portada nos aproxima al relato histórico que pone en el centro del proceso emancipador al general don José de San Martín y al Libertador Simón Bolívar. Pons Muzzo, además de concentrar su relato en diversos personajes destacados o ilustres, ubicará a Lima como núcleo de todo el proceso. En un contexto donde predominan las «figuras de bronce» (próceres y precursores de la independencia), el autor ela- 


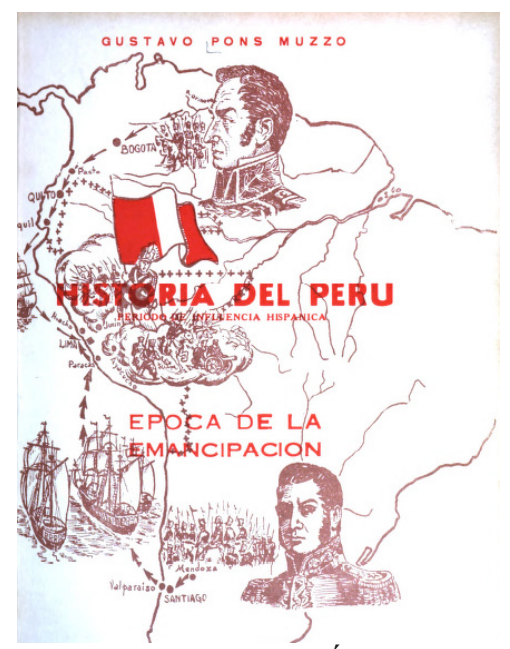

Figura 1. Portada del libro de Historia del Perú. Época de la Emancipación de Gustavo Pons Muzzo (1957)

borará un relato cuyo hilo conductor es la trayectoria de los patriotas criollos peruanos y americanos.

Por otro lado, la aproximación de Pons Muzzo a la temática de los indígenas y la emancipación consiste en situarlos como grupos rebeldes que antecedieron las luchas criollas por la libertad. Aunque reconoce la importancia de los movimientos de Santos Atahualpa y Túpac Amaru II, les dedica poco espacio, sintetizando solo algunos datos. Escribe Pons Muzzo (1957, 15-16; el énfasis es nuetro).

En el siglo XVII en todas partes se mantuvo el espíritu de rebeldía de los indios. Pero fue en el siglo XVIII cuando se produjeron las más importantes de estas rebeliones. Tales fueron en el Perú, la del mestizo Juan Santos Atahualpa en las montañas de Tarma, Huánuco y Jauja (1742-56) y la de Túpac Amaru (1780-81) que mantuvo el Perú y la región de Charcas alborotada hasta 1733 [...]. No fueron sino movimientos de protesta contra la dominación española imperante, que no obstante las buenas leyes dictadas por los monarcas españoles, mantenían un estado de permanente inquietud entre los gobernados.

A lo largo del texto, no habrá algún desarrollo de la rebelión de Santos Atahualpa en la selva central, pero sí un desarrollo parcial de la rebelión de Túpac Amaru II, un recuento escueto de las causas de la rebelión y los acontecimientos que culminan con su ejecución en el Cusco. Pons Muzzo evita 
cualquier reflexión sobre la importancia de la rebelión tupacamarista o sus consecuencias. Esta es presentada como un antecedente de la emancipación, y se ubica a Túpac Amaru como un precursor, junto con líderes criollos como Toribio Rodríguez de Mendoza. Ello contrasta con el desarrollo más o menos amplio que realizará Pablo Macera sobre las rebeliones de Santos Atahualpa y Túpac Amaru II, en su texto escolar de 1986.

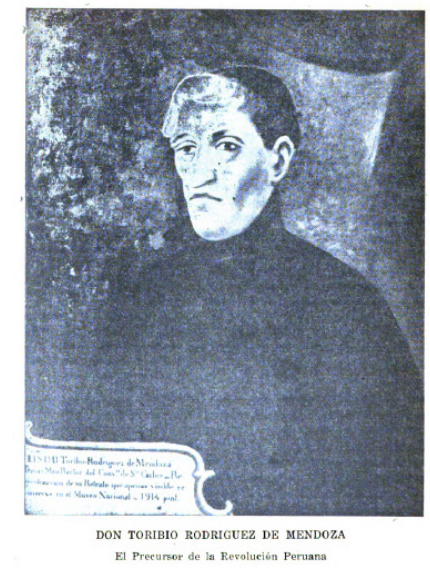

Figura 2. Don Toribio Rodríguez de Mendoza. El precursor de la revolución peruana Fuente: Pons Muzzo $(1957,42)$

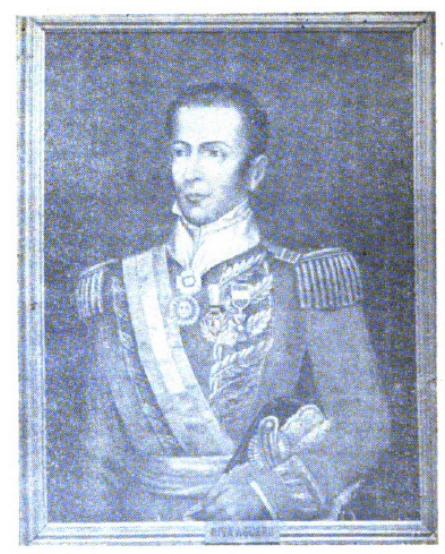

Figura 3. Don José de la Riva Agüero. Prócer de la Independencia Nacional Fuente: Pons Muzzo $(1957,164)$

Resultan de interés las lecturas que selecciona Pons Muzzo para complementar las descripciones y explicaciones que realiza en su manual escolar. Entre ellas se observan textos de Vicuña Mackena, José Antonio de Lavalle, 
Bartolomé Mitre, Mariano Paz Soldán, Luis Alayza, Carlos Wiesse, Jorge Basadre y Víctor Andrés Belaunde. A estos textos, se agregan fragmentos de fuentes primarias como la Carta a los españoles americanos de Vizcardo y Guzmán, el acta de Independencia (1821), las memorias del general O Leary sobre Bolívar o el elogio a Bolívar de J. D. Choquehuanca.

La historiadora Cecilia Méndez ha señalado la permanencia de una mirada limeñocentrista sobre la independencia. La centralidad otorgada a la proclamación de la independencia por San Martín en Lima (28 de julio de 1821), después de 1850, ha reducido las posibilidades de ver la independencia desde las regiones y provincias, hasta hoy. Como parte de la presentación del proyecto «Las independencias antes de la Independencia» (2014), promovido por Cecilia Méndez y Juan Carlos Estenssoro, se indica que:

El Perú será el último país latinoamericano en celebrar el bicentenario de su independencia, pues es el único que la conmemora el día en que se declaró y no el inicio del proceso que condujo a ella. La independencia oficial se identifica con la proclama de San Martín en Lima a tal punto que parece imposible evocarla por ningún otro acontecimiento. Pero esta no fue, ni es, la única memoria posible. Antes de 1821 se produjeron rebeliones y juntas: Tacna en 1811 y 1813 , Huánuco en 1812, Cuzco en 1814-1815. Hoy se habla poco de ellas pese a que se han cumplido, o están cumpliéndose, sus bicentenarios. ¿Por qué no se escogió como hito fundador una insurrección temprana o la batalla de Ayacucho que selló realmente la independencia del país y del subcontinente? ¿Por qué ya nadie menciona las rebeliones indígenas, ni a Túpac Amaru, como se hacía hace unas décadas? (Méndez y Estenssoro 2014).

El texto de Pons Muzzo se inscribe en la tendencia tradicional de observar la independencia principalmente desde Lima, destacando el protagonismo criollo y las fuerzas extranjeras. Desarrolla sintéticamente las rebeliones de Tacna, Huánuco y Cusco, destacando el liderazgo de Mateo Pumacahua: «Este movimiento de criollos e indios fue el más grande esfuerzo que realizamos los peruanos para alcanzar la independencia por sí solos» (Pons Muzzo 1957, 87); e incluye un breve texto sobre la conspiración de Aguilar y Ubalde en el Cusco. Posteriormente se alude a las montoneras o guerrillas indígenas, pero sin mayor desarrollo. Las lecturas complementarias giran en torno a los libertadores y otros líderes criollos, siendo el pescador José Olaya el único héroe popular que se incluye. Las memorias de la lucha desde los pueblos 
mestizos-indígenas tienen poco o nulo espacio en la narrativa historiográfica criolla de mediados del siglo XX. Esta, además, se concentra en los hechos políticos-militares, siendo lo social-cultural todavía un elemento prácticamente relegado.

Cabe subrayar que Pons Muzzo refleja claramente en su texto escolar la tradición inaugurada por autores decimonónicos como Lorente y Vicuña Mackenna. El historiador Antonio Espinoza $(2012,395)$ refiere los cambios introducidos por estos autores:

Alrededor de 1860 se produjeron dos innovaciones historiográficas que se reflejaron en los libros de texto. El educador español Sebastián Lorente afirmó la utilidad de la enseñanza histórica para unir a los peruanos y fortalecer su patriotismo. Paralelamente, el historiador chileno Benjamín Vicuña Mackenna introdujo la figura de los «precursores» de la independencia peruana, intelectuales que habían preparado las condiciones para las expediciones libertadoras de los generales San Martín y Bolívar.

Como parte del propósito de afirmar la peruanidad, Pons Muzzo incluye dos capítulos finales en su manual: «El esfuerzo peruano por la Independencia del Perú y de América» (capítulo XVIII) y «Los símbolos y expresiones perdurables de la Independencia» (capítulo XIX). El primero se concentra en algunos precursores criollos de la independencia, y el aporte peruano a las campañas finales; mientras el segundo, describe el territorio, los símbolos patrios, las supervivencias coloniales y reflexiona sobre el caudillismo y la demagogia, aunque se limita a un solo párrafo, que además cierra el libro.

Actitud del Perú en la guerra emancipadora. El Perú contribuyó pues, a la independencia del Continente. Necesitó la ayuda chilena, argentina y colombiana, no porque fuera impotente y falto de espíritu revolucionario, sino porque el Perú tenía en América una importancia continental y porque la guerra fue un hecho de caracteres continentales. El Perú cumplió su misión, aunque para cumplirla tuviera que adquirir deudas con los países vecinos. El Perú agradece a O'Higgins, San Martín y Bolívar la ayuda prestada para conseguir su independencia y la del continente todo (Pons Muzzo 1957, 215; el énfasis es nuestro).

Supervivencias coloniales. A pesar de que la República había declarado la igualdad de todos los peruanos frente a la ley, continuaron un tanto las diferencias raciales y el indio continuó un tiempo su estado de postración de los tiempos 
coloniales. Es cuestión del presente siglo el que los gobiernos se preocupen por la raza indígena. Hoy esas diferencias han desaparecido (Pons Muzzo 1957, 224; el énfasis es nuestro).

Caudillaje y demagogia. El Perú, como los demás países de América española, era un pueblo que nunca había intervenido en el gobierno, un pueblo que no sabía gobernar se así mismo. Esta difícil tarea de aprender a gobernarnos, por nosotros mismos ha sido muy dura. En los primeros tiempos de la República daría lugar a la aparición de los caudillos y demagogos; entraría en una etapa dolorosa y delicada, que no sería sino el esfuerzo que hacía nuestro pueblo por realizar la verdadera democracia como la quisieron los padres de la patria. Con la República surgió una gran posibilidad y una grave responsabilidad (Pons Muzzo 1957, 225; el énfasis es nuestro).

El libro de Pons Muzzo se caracteriza por ser marcadamente descriptivo, de explicaciones breves y comentarios reflexivos ocasionales. Como señala Gonzalo Portocarrero $(1989,84)$, el análisis crítico de los textos escolares de Pons Muzzo debe proceder no mediante el análisis de lo dicho explícitamente, sino mediante el examen de lo encubierto o reprimido. En ese sentido, debe considerarse que en el discurso histórico de Pons Muzzo hay una narrativa patriótica criolla, de «inclusión subordinada» (Guillermo Nugent) hacia el indio-mestizo; ellos constituyen «los otros», quienes deben ser asimilados al proyecto nacional. La nación peruana (o criolla) fue artífice también de su independencia; esta no fue solo otorgada por agentes externos, y su gran reto es superar el caudillaje y demagogia política, además de redimir al indio históricamente postrado. Pons Muzzo da continuidad al relato nacional de intelectuales conservadores como Sebastián Lorente, Carlos Wiesse, Riva Agüero y Víctor Andrés Belaunde ${ }^{7}$

7 Aunque algunos de ellos figuran como representantes del pensamiento liberal (Lorente), y otros fueron liberales en su juventud (Riva Agüero), en general adoptaron un pensamiento que hoy podríamos calificar como conservador o ultraconservador. Lorente era liberal políticamente, pero no socialmente. Los liberales decimonónicos podían ser autoritarios, además de paternalistas, frente a los indígenas, a quienes podían despreciar, a pesar de enarbolar su defensa formal desde las leyes. 


\section{Pablo Macera y el discurso histórico sobre la independencia en los textos escolares}

Por su parte, el historiador Pablo Macera (1929-2020), nacido en Huacho, pero afincado en la ciudad de Lima, fue un destacado intelectual e influyente maestro de generaciones de estudiantes universitarios. Graduado en la Universidad San Marcos, se desempeñó como docente en esa misma institución por décadas, fundando además el Instituto Seminario de Historia Rural Andina (ISHRA), el cual evidenciaba su interés por promover una investigación histórica de los grupos subalternos (cultura andina y amazónica, historia campesina, arte popular, etc.). Discípulo de Porras Barrenechea, tomó distancia de la historia conservadora de este reconocido maestro, y desarrolló una historia nacional crítica, basada en la denuncia del colonialismo, el fracaso de la república criolla y la revalorización de la cultura andina-amazónica, compartiendo esta postura con autores como Luis Guillermo Lumbreras y Alberto Flores Galindo (Burga 2005, 66). Formado en diversas corrientes teóricas e historiográficas, fue próximo a la Escuela de los Annales, al marxismo y a la teoría de la dependencia, entre otras. Sobre Pablo Macera y su obra, el historiador Manuel Burga $(2005,192)$ ha referido:

En sus esquemas generales de interpretación, como el expresado en su libro Visión histórica del Perú (del paleolitico al proceso de 1968), Lima, 1978, en los cuales se puede encontrar una notable influencia de José Carlos Mariátegui, comienza a entender nuestro proceso histórico como la historia de una enorme derrota, una continuada frustración y como la degradación constante de las poblaciones indígenas, quienes eran los legítimos — según él- dueños de los territorios peruanos y los que aportaban la originalidad y singularidad de la nación peruana. Su interés por el descubrimiento de lo andino se vuelve desbordante y apasionado: la historia, de acuerdo con él, adquiere su validez y utilidad social en tanto contribuye a revelar la historia de la explotación y de la marginalidad de las poblaciones andinas. Conquistadas y explotadas por los colonizadores españoles y nuevamente explotadas y marginalizadas por los criollos durante el período republicano.

Pablo Macera promueve una visión crítica hacia el Estado criollo y la dependencia hacia potencias extranjeras. Reivindica las luchas populares y las identidades indígenas andino-amazónico. Fue un autor muy influyente, cuya 
obra contribuyó a la «idea crítica», ${ }^{8}$ que surgió en el magisterio entre los años setenta y ochenta, la cual promovía una visión histórica distinta a la oficial. Próximo a algunas tesis de historiadores como Juan José Vega, Heraclio Bonilla y Virgilio Roel Pineda, cuestionó los fundamentos del nacionalismo criollo-limeño, aproximándose en parte al indigenismo de autores como Luis E. Valcárcel.

Pablo Macera no presenta un prefacio en Historia del Perú. Independencia y República 3 (1986), pero incorpora consideraciones diversas sobre el enfoque histórico que emplea. En el capítulo «Concepto y cronología», explica su rechazo al concepto de «emancipación», y establece su criterio de abarcar en el curso de tercer año de secundaria el periodo comprendido entre los inicios de la independencia y la guerra con España (1866). Se adhiere a la idea de no culminar el curso con el capítulo de la guerra del Pacífico: «Te gustaría que al llegar diciembre termines tu año escolar recordando la derrota frente a Chile? ¿No sería deprimente? ¿En eso, en esa derrota, terminaba todo el proceso histórico peruano de la independencia y la república?» (Macera 1986, 5). En este punto, Macera procura cierta empatía con sus lectores escolares, buscando alejarlos del sentimiento de abatimiento en que muchas veces se cae, al revisar una historia marcada por derrotas y fracasos. Resulta interesante observar, además, cómo el autor propone una especie de diálogo con los lectores, usando el modo de segunda persona y empleando un «nosotros», práctica que contrasta con la narrativa principal de los textos actuales, como Santillana, donde el relato (descripción-explicación) es regularmente neutro e impersonal.

Macera realiza la clásica distinción entre movimientos indígenas y criollos, denominándolos «movimientos criollos de liberación colonial» y «mo-

8 La «idea crítica» es un concepto propuesto por Gonzalo Portocarrero y Patricia Oliart (1989), que refiere la visión o discurso sobre la realidad nacional, que emerge entre sectores populares y espacios universitarios, y tendrá especial divulgación entre maestros en la segunda mitad del siglo XX. Se trata de un discurso simplificador y estereotipado, donde la historia del Perú está marcada por un sentimiento de frustración y fracaso. La derrota del idílico Imperio inca; la instauración de la opresión colonial bajo los hispanos; el saqueo de las riquezas nacionales por España, Inglaterra y los Estados Unidos, debido al imperialismo y la situación de dependencia; así como la presencia de Gobiernos criollos corruptos e incapaces durante toda la república. A las críticas de antaño, se suma la influencia del discurso marxista (materialismo dialéctico e histórico) en los sesenta, que acentúa la visión crítica de la realidad nacional, denunciándose especialmente el imperialismo norteamericano y la dependencia económica del país. El concepto de la «idea crítica» es útil para identificar cierto imaginario histórico-nacional, marcado por un nacionalismo desde abajo. Como contraparte, la «idea oficial» del Perú, promovida en las escuelas, se basaba en un nacionalismo complaciente, que sobrevaluaba la integración social, y mostraba optimismo en la desaparición paulatina de la explotación y los abusos. Declaraba al Perú como una nación mestiza desde la colonia, y no da cabida para pensar en otras identidades, como la indígena. A pesar del valor del concepto de la «idea crítica», esta puede ser reduccionista frente las visiones alternativas y el radicalismo político de antaño. 
vimientos nativos de liberación colonial». El autor plantea la siguiente interrogante: «¿Qué clase de independencia fue conseguida por el Perú en 1824? ¿Nativa? ¿Criolla? La respuesta debes buscarla y darla tú mismo. El deber de nosotros como historiadores y profesores es proporcionarte los materiales para que tú construyas tu propia casa, la casa de tu historia» (Macera 1986, 8). La tesis de Macera, propia de la historia crítica de la época, es que la independencia fue criolla (aunque inviable sin los movimientos indígenas), pero se trató de una revolución política y no de una revolución social.

Sobre el término «emancipación» (empleado por distintos historiadores, entre ellos Pons Muzzo), el historiador Pablo Macera declara su rechazo a este, y advierte a los estudiantes sobre la inconveniencia de este concepto. Dice Pablo Macera (1986, 7):

¿Independencia o Emancipación?.- Empezaremos nuestros estudios del presente año con una indicación: Preferimos usar el término Independencia y no el término Emancipación. La Emancipación es una figura jurídica por la cual $1^{\circ} \mathrm{El}$ padre concede mayoría de edad a sus hijos. $2^{\circ} \mathrm{El}$ patrón concede libertad a sus esclavos. Resulta incorrecto este término Emancipación para definir la lucha de los peruanos por conseguir su autonomía política. Por las siguientes razones: 1) La relación entre España y los peruanos no fue la de un padre respecto a sus hijos, ni la de un patrón respecto a sus esclavos. Y, 2) España no concedió la libertad, no emancipó a su hijo-esclavo (el Perú). Por el contrario, España se resistió a la separación de su colonia.

En la portada del libro de Pablo Macera, se observa a un hombre andino soplando el wacrapucro o toro-corneta, instrumento musical tradicional de la sierra central y sur del Perú, declarado patrimonio cultural de la nación el 2013. La portada nos aproxima a una constante en el libro: el reemplazo parcial de las tradicionales ilustraciones de libros, como los de Pons Muzzo (cuadros de grandes personajes), por imágenes del arte andino (cerámica, murales, textiles, retablos, etc.) alusivos a la independencia o a la sociedad peruana en la sierra. Pablo Macera, investigador y coleccionista destacado del arte popular peruano, al parecer decidió, personalmente, incluir estas imágenes de la nación peruana «no oficial». Mientras los textos oficiales de historia, de autores como Carlos Wiesse o Pons Muzzo (además de José Antonio del Busto), se aproximaban a la ideología del mestizaje, Pablo Macera presentaba un texto más próximo a la identidad andina, la cual busca representar. 


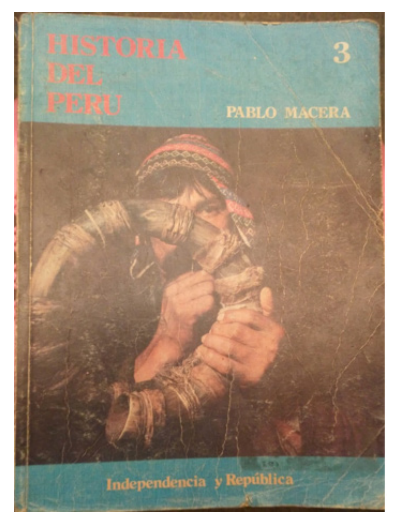

Figura 4. Portada del libro Historia del Perú. Independencia y República de Pablo Macera (1986)

El libro escolar de Pablo Macera refleja algunas ideas y planteamientos que Macera ya había expresado en textos dispersos y especialmente en el libro Visión histórica del Perú (Del paleolítico al proceso de 1968) (1978). Crítico hacia la historiografía tradicional criolla, e influido por un discurso reivindicador andinista, Macera ofrece una mirada histórica alternativa a la historia oficial o conservadora, por lo que toma distancia de las posiciones de su maestro, el historiador Raúl Porras Barrenechea:

En vez de una sola y unitaria historia del Perú quizás convenga hablar de las diferentes historias ocurridas en el territorio que desde hace pocos años - a partir del siglo XVI - se ha empezado a llamar PERÚ; como el de Alemania e Italia; el periodo «nacional» de la historia del Perú comenzó tardíamente, a principios del siglo XIX, después de su ruptura política con España (1821-1824). Aún hoy el estado peruano es una organización multinacional, con relaciones internas de dependencia y discriminación étnica. Menos parecida a la Francia nacional moderna que al imperio Austro-Húngaro o los países africanos recién descolonizados (Macera, 1978, p. 1).

Macera explica que el esfuerzo de waris, incas e incluso la modernización capitalista no pudieron homogeneizar el Perú. En ese sentido, afirma lo siguiente:

Esta hipótesis acerca de la multivalencia del concepto y de la realidad Perú es analítica y descriptiva; no arriesga ningún pronóstico contra la realización de una nación peruana en el futuro inmediato; lo que es más, postula a esa realiza- 
ción como un objetivo histórico probable y positivo; pero se opone a la ideología ultranacional criolla elaborada a principios del siglo XIX y que sostiene la existencia de un Perú permanente; es decir una entidad histórica de larga duración; idéntica a sí misma desde hace miles de años (del precerámico a Bolívar y Belaunde o Velasco); entidad que sería el actor responsable de todos y cada uno de los procesos históricos gestionados por las diferentes sociedades que han ocupado el mismo territorio. Creer en ese Perú metafísico y trascendental es pensar la historia en términos religiosos (Macera 1978, 2; los énfasis son nuestros).

Macera critica la visión de un conjunto de pueblos «peruanos» en diversas épocas igualmente «peruanas», que no alteran su propia sustancia. Se opone a la identificación del Perú como una creación sumerio-católica, donde además cada época supone un mejoramiento de la anterior. «La interpretación que proponemos no desconoce la interrelación ocurrida entre algunos de los procesos históricos que plantean al Perú como problema y posibilidad (Basadre)» (Macera 1978, 3). Macera reconoce múltiples discontinuidades e interrelaciones en la seriación cronológica del Perú, sin que deba identificarse necesariamente como un esquema evolutivo. Distingue dos grandes épocas: autonomía (20 000 aprox. a. C, hasta el siglo XVI d. C) y dependencia (siglos XVI al $\mathrm{XX}$ ). La diferencia entre ambas etapas es que ninguna de las expansiones o imperios andinos, previos a la invasión europea, significaron dominaciones externas o ultramarinas; así como tampoco significaron la derogación total de los universos socioculturales de los dominados; ni era considerable la distancia tecnológica dentro de los sistemas de dependencia. Lo contrario ocurre a partir del siglo XVI, cuando la civilización andina es incorporada a la historia universal de la civilización europea u occidental (Macera 1978, 13). En el siglo XIX, el Perú logra su independencia política, mas no social. El país experimenta una segunda apertura a los mercados mundiales, y depende del imperialismo informal inglés: «El Perú se convierte es un estuario del Támesis».

En Historia del Perú. Independencia y República (1986), Pablo Macera, tras sus consideraciones sobre el concepto histórico y la cronología, comienza con una descripción más o menos detallada de la sociedad colonial (capítulo II). Afirma que la revolución de la independencia fue un proceso económico, social, político e ideológico, «un proceso tan complejo que no puede ser explicado únicamente como un resultado de la influencia de las ideas francesas, inglesas, norteamericanas, españolas o peruanas. Porque las ideas también a su vez son hechos sociales y tienen sus orígenes en causas sociales» (Macera 
1986, 10). Considera que el modo adecuado de entender la independencia es buscando la explicación en la misma sociedad americana y peruana de la época.

En el capítulo dedicado a sociedad colonial, Macera explica la composición social del virreinato, y se detiene en actividades económicas como la agricultura y la minería colonial. Dedica un análisis de la condición de trabajador moderno, el cual percibe un salario, a diferencia del trabajo de los esclavos y siervos. «Pensar en un obrero indio o un obrero negro les hubiera causado escalofríos (a los propietarios de tierras)» (Macera 1978, 13). La economía colonial se tornaba débil al basarse solo en el trabajo de siervos y esclavos, distando de la economía basada en salarios de la era moderna. Por otro lado, Macera $(1978,13)$ indica que «el verdadero centro de la economía peruana no era la Agricultura sino la Minería». Se pregunta sobre lo que significó la producción de plata en términos de trabajo y tiempo; para responder, recurre al historiador Pierre Chaunu, estableciendo que la diferencia en el número de trabajadores, de horas-hombre de trabajo, significa la medida de la explotación, sobre-explotación del hombre americano de la plata, en comparación al hombre europeo del trigo. Macera $(1978,14)$ cita a Pierre Chaunu: «La empresa minera americana solo era posible a condición de que el trabajo del indio fuera casi gratuito... forzado y remunerado por debajo del costo real de producción y de reproducción del hombre».

Macera refiere que la tarea de la ciencia histórica y social consiste en hacer visible y poner en evidencia la relación directa y oculta entre lo social y lo político. Gracias a ello «comprenderemos la relación que existe entre la sobre-explotación de los trabajadores mineros, la importación de mercaderías europeas o la salida de los metales preciosos y todo el movimiento primero indio y después criollo que concluyó en la ruptura final entre el Perú y el Imperio español» (Macera 1978, 18). Explica, además, que las relaciones entre personas y países solo se rompen cuando empiezan a ser inconvenientes para alguien en un grado mayor al soportable, y también cuando existe conciencia sobre ello, planteándose así que hay una salida, una opción distinta.

Para los Andinos y Amazónicos el coloniaje había sido insoportable durante todo el tiempo desde el siglo XVI en adelante. Por eso su proceso de Independencia (frustrado), su movimiento propio de liberación nacional, fue continuo y arranca desde Manco Inca a lo largo de los siglos XVI y XVII hasta Santos Atahualpa y Túpac Amaru II [...] muchos fueron los descontentos. Indios, criollos, hasta los 
propios españoles. Ricos o pobres. Ninguno recibía del Sistema lo mismo que antes recibía. Recibía menos. Se fueron creando así las condiciones prerrevolucionarias. Las revoluciones ocurren no tanto porque haya gente a favor de la revolución. Sino porque cada vez hay menos gente a favor del Sistema (Macera 1986, 18-19; énfasis del autor).

Macera resalta el malestar de los pueblos indígenas desde la misma colonización, y agrega el creciente descontento de una aristocracia criolla empobrecida en el siglo XVIII. El siglo XVII fue el «siglo criollo», el siglo de los hacendados, los latifundios y los propietarios de tierras, describe el autor. «Una aristocracia empobrecida resulta peligrosa. Un refrán dice No mandes a quien mandó ni sirvas a quien sirvió» (Macera 1986, 18).

El análisis de Macera sobre el funcionamiento del mercado, el salario y su empleo de terminologías como «condiciones prerrevolucionarias», provienen de la influencia del análisis marxista en la historiografía de la época. Sin embargo, se aprecia también la influencia de la teoría de la dependencia y su formación en la Escuela de los Annales. La reivindicación de la identidad andina atraviesa su obra y se expresará de varias formas en el texto escolar que se analiza en el presente artículo. Por ejemplo, en el espacio dedicado a desarrollar las rebeliones indígenas e interpretar su significado para la historia peruana, así como describir o mostrar la cultura popular andina en varias páginas del manual escolar.

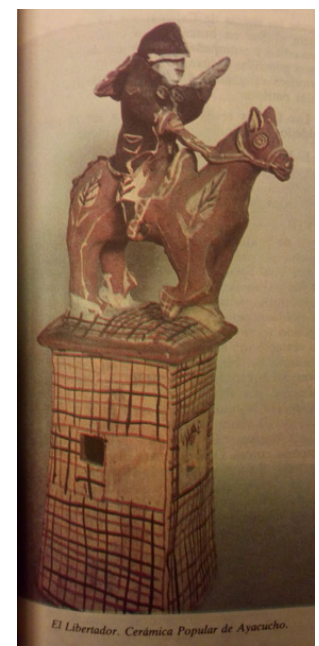

Figura 5. El Libertador. Cerámica popular de Ayacucho.

Fuente: Macera $(1986,99)$ 
Mientras en las páginas del libro de Pons Muzzo predominan cuadros solemnes de virreyes, precursores, próceres o libertadores, así como cuadros paradigmáticos tales como la Proclamación de la Independencia (Juan Lepiani, 1904) o La capitulación de Ayacucho (Daniel Hernández, 1924), en el manual escolar de Macera se alternan cuadros retratos de personajes destacados, con imágenes del arte popular andino (mate burilado, textiles, keros, murales), acuarelas de Pancho Fierro, grabados diversos y pinturas populares de eventos nunca analizados en los textos oficiales, como la revolución de esclavos en Haití.

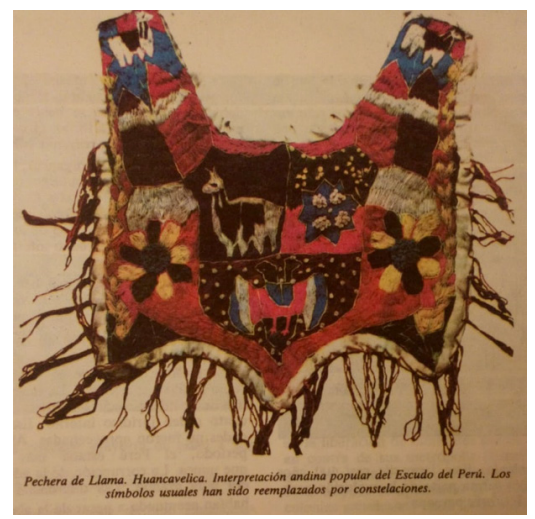

Figura 6. El Libertador. Pechera de Llama. Interpretación andina popular del Escudo del Perú. Los símbolos usuales han sido reemplazados por constelaciones

Fuente: Macera $(1986,5)$

Macera rompe con la estructura tradicional de los textos escolares, e incluye representaciones inusuales en los manuales. Este rescate del arte de la nación peruana-andina, y su visibilización en textos de distribución con gran alcance, constituye un hito saludable en la historia de los manuales escolares de historia del Perú. Gonzalo Portocarrero ya había subrayado el carácter novedoso o irruptor de los textos escolares de Pablo Macera al referirse al libro Historia del Perú. La Colonia (1984), dirigido al segundo grado de educación secundaria:

El texto Historia del Perú: La Colonia, de Pablo Macera, marca una ruptura profunda en la divulgación escolar. Frente a la imagen tradicional de la Colonia como periodo marcado por la quietud, el acercamiento y la fusión, Macera propone una imagen distinta en la que lo central sería la jerarquización étnico-cultural, la dominación y la resistencia indígena [...] el Perú es una nación que se está haciendo; es decir, más una tarea pendiente que un legado (Portocarrero 1989, 88). 
Un aspecto diferente de la obra de Macera, además, es su acercamiento a los jóvenes lectores, mediante el uso del lenguaje en segunda persona, la pregunta directa a los escolares y la invitación a pensar en términos ucrónicos y prospectivos. Así, por ejemplo, al cerrar la explicación sobre la rebelión de Túpac Amaru II, Macera introduce un segmento denominado «Comentarios», donde escribe:

Supongamos que Túpac Amaru hubiese triunfado. ¿Sería el Perú de hoy diferente al que vivimos? ¿Mejor? [...] enunciaremos algunas consecuencias previsibles [...] 2. Las masas indígenas hubieran tenido un acceso o una representación directa al poder político. 3. La capital del Nuevo Perú Independiente hubiera sido el Cusco en la Sierra y no Lima en la costa [...] 5. El prejuicio racial blanco hubiese perdido su razón de ser [...] 7. La gravitación del Cusco como Capital del Nuevo Perú hubiera probablemente impedido la separación o división del Alto-Perú (Bolivia). Quizá hubiera evitado la Guerra con Chile [...] 10. ¿Cómo hubieran reaccionado las élites criollas de la costa? (Macera, 1986, p. 27).

Estas interrogantes plantean el escenario de pensar el Perú como un Estado no criollo y dirigido por sectores indígenas. La centralidad de Lima (costa) es reemplazada por la antigua capital incaica, Cusco (sierra sur). No son preguntas gratuitas, sino pensadas para romper los esquemas o paradigmas, bajo los cuales la historia oficial propone pensar la historia nacional. Macera, mientras cuestiona el carácter moderado del Mercurio Peruano (y, por lo tanto, de sus miembros criollos), reivindica el valor de las rebeliones indígenas del siglo XVIII, provenientes de zonas no costeñas o capitalina. Posteriormente, trasladará su reivindicación de lo andino hacia los símbolos nacionales: «La creación de símbolos fue una tarea revolucionaria en el Perú a principios del siglo XIX. Los patriotas emplearon diversos medios. Sueños (Aguilar), Pintura y Poesía (Túpac Amaru, Melgar). ¿Música?» (Macera 1986, 59).

En el capítulo XVI, «Perú Independiente: Problema y Posibilidad», Macera realiza un balance sobre la independencia, en el cual hace notar la abundancia de estudios sobre esta etapa. Lo atribuye a dos posibles factores. El primero vinculado a la existencia historiadores que «ven en la Independencia no tanto una revolución como más bien el origen del sistema social en el cual esos grupos y esos historiadores viven. Elogiar y defender la Independencia no es elogiar a los héroes y las víctimas (Túpac Amaru, Bolívar, Vizcardo). Resultaría más bien una forma de elogiar y defender todo el sistema sin criti- 
carlo» (Macera 1986, 111). La otra explicación al enorme interés de los historiadores por la independencia puede ser debido a la promesa que la misma independencia significó: «El interés por la independencia es una forma de conocer correctamente esa promesa y esa esperanza y de preguntarnos todos: ¿Qué ha ocurrido para que esas promesas no se cumplan; para que esas esperanzas se frustren?» (Macera 1986, 111). El libro de Macera critica así a cierta historiografía y propone una sociología de la historia que supera la tradicional descripción de sucesos históricos bajo un esquema episódico o lineal, típico en los libros escolares peruanos.

\section{Editorial Santillana y el discurso histórico sobre la independencia en los textos escolares}

Editorial Santillana es una editorial española perteneciente al poderoso Grupo PRISA. Especializada en la elaboración de textos educativos, y con presencia en varios países, actualmente es la más importante en el Perú a nivel de textos escolares de ciencias sociales (historia, geografía y economía). Esta editorial elabora libros de autoría múltiple, con la asesoría de historiadores y educadores especializados. Sigue estrictamente los lineamientos curriculares del Ministerio de Educación en los concursos para la elaboración de libros escolares de distribucional nacional. Los libros que presenta son de lenguaje neutro y crítica atenuada, incorporando avances de la historiografía peruana o peruanista de las últimas décadas. Bajo el modelo socio-constructivista, enfatiza el desarrollo de las competencias propuestas por el Currículo Nacional. En el Perú, la editorial es dirigida por el historiador Juan Fonseca.

El libro Ciencias Sociales 3 (2020) de la Editorial Santillana, al igual que otros textos escolares recientes (editoriales Norma y San Marcos), prescinde de los antiguos prefacios y opta por presentar el programa de estudio, adaptado al diseño curricular por competencias, capacidades y desempeños. A diferencia de los programas de estudio de décadas anteriores, el Currículo Nacional ya no distribuye los cursos por asignaturas, sino por áreas. Mientras entre los cincuenta y ochenta se estudiaban las asignaturas de Historia del Perú, Historia Universal, Geografía, Economía, entre otras, desde los años noventa, con la reforma educativa del Gobierno neoliberal de Alberto Fujimori, se introduce el área de Ciencias Sociales, la cual abarca todas las asignaturas mencionadas. El curso de Historia del Perú actualmente se desarrolla solo en 
algunas pocas unidades del área de Ciencias Sociales, lo cual constituye un problema para la enseñanza efectiva de este curso.

El Currículo Nacional de Educación Básica vigente establece como competencia del área de Ciencias Sociales: «Construye interpretaciones históricas», la cual tiene como capacidades: «1. Interpreta críticamente fuentes diversas»; «2. Comprende el tiempo histórico»; y «3. Elabora explicaciones sobre procesos históricos». En la Unidad 4. Crisis del orden colonial, el libro Ciencias Sociales 3 de la Editorial Santillana presenta el recuadro «Aprenderemos a...», en el cual se establece:

Comprender el tiempo histórico, interpretar críticamente fuentes históricas diversas y elaborar explicaciones históricas sobre la crisis del orden colonial en el Perú a inicios del siglo XVIII y el contexto de la independencia. De esa manera, lograremos construir interpretaciones históricas sobre los procesos estudiados. Todo ello a partir del análisis de la idea de nación en el Perú y la riqueza de su diversidad (Santillana 2020, 145).

El discurso histórico presente en texto escolar se caracteriza por una aproximación marcadamente descriptiva y de explicación académica (e imparcial) de los sucesos. Se evita enjuiciamientos históricos o valoraciones, y se propone una historia académica de tono mesurado o aséptico. El manual reúne varias voces y podría ser calificado de «polifónico», pero la línea general es el de discurso académico adaptado para un público no especializado. No se prescinde del fomento de una identidad nacional, pero se aleja de la exaltación nacional de los manuales escolares de antaño. A lo largo del texto, se citan a numerosos historiadores (Scarlett O'Phelan, Carlos Contreras, Pedro Guibovich, José Agustín de la Puente Candamo, etc.) para la explicación de los hechos estudiados. Sin embargo, son citas breves, hilvanas en una explicación general también corta.

Las rebeliones peruanas. Entre 1808 y 1816, mientras en el resto de América los movimientos insurgentes alcanzaban importantes avances, en el Perú se impuso un férreo control realista que impidió el éxito de las primeras rebeliones separatistas. Estas rebeliones constituyen la evidencia de que, durante la primera etapa de la lucha por la independencia, en el Perú hubo un importante sector favorable a la separación política de España (Santillana 2020, 91). 
La breve introducción a las rebeliones peruanas de inicios del siglo XIX se alinea con la tesis de la «independencia conseguida», según la cual gracias a los diversos movimientos rebeldes se sentó las bases para la fase final del proceso separatista (las corrientes libertadoras de San Martín y Bolívar). ${ }^{9}$ Una limitación en la explicación es no mencionar las causas que llevaron al surgimiento de estos movimientos, pareciendo que se considera esto como algo sobreentendido.

La gran rebelión del Cusco. Este gran movimiento insurgente se desarrolló entre 1814 y 1815 . Estuvo liderado por los hermanos José, Vicente y Mariano Angulo y por Mateo Pumacahua, curaca de Chinchero. El levantamiento se inició en agosto de 1814 con la captura de los oidores de la Audiencia del Cusco y la proclamación de la Junta de Gobierno de las Provincias Unidas del Sur. Por su magnitud, esta rebelión es considerada la segunda gran rebelión del Cusco, y se la compara con la de Túpac Amaru II [...]. Según la historiadora Scarlett O’Phelan, la sangrienta represión de esta rebelión apagó momentáneamente el ímpetu revolucionario del sur andino. Por esa razón, esta región se convirtió en un bastión de la resistencia realista durante las campañas de independencia del Perú de los años siguientes. (Santillana 2020, 92).

En la sección explicativa sobre la rebelión del Cusco de 1814, se da cuenta de la importancia del movimiento y se alude a la dura represión tras la derrota. Señala una de las consecuencias, que fue convertirse en bastión de las fuerzas realistas del virrey La Serna. El texto conserva la precisión de la glosa breve y no ofrece mayor detalle. Se descarta, por ejemplo, describir en qué consistió la «sangrienta represión» (decapitación de Pumacahua y exhibición pública de sus miembros descuartizados). Al igual que muchos textos de historia escolar, se produce una suerte de autocensura, en relación con muertes violentas (torturas), violencia sexual o abusos diversos.

Un elemento valioso del manual de Santillana es el libro de actividades. En este, se propone, por ejemplo, analizar una reflexión de Jorge Basadre en El azar en la historia y sus límites (1971) sobre las posibles consecuencias que habría traído una victoria de Mateo Pumacahua y los hermanos Angulo

9 La tesis de la independencia conseguida se expresa con más claridad en la introducción al capítulo «Las Corrientes libertadoras del Perú»: «El Perú fue el último reducto realista en América. Por ello, hasta aquí convergieron las expediciones libertadoras del sur, al mando de José de San Martín, y del norte, dirigidas por Simón Bolívar. Las acciones de estas fuerzas y la labor de los grupos patriotas del país permitieron la consolidación de la independencia del Perú» (Santillana 2020, 100). 
en la rebelión del Cusco de 1814, como generar una nación más integrada y un poder político repartido entre indios, mestizos y criollos $(2020,72)$. Más adelante, en el libro de texto $(2020,96)$, se plantea a los estudiantes el análisis de las posturas historiográficas en torno a si existía o no una conciencia nacional durante la independencia, contraponiéndose un texto del historiador José de la Puente Candamo (el peruanismo en el Mercurio Peruano) y un texto de Bonilla y Spalding, donde se cuestiona la idea de la nación mestiza.

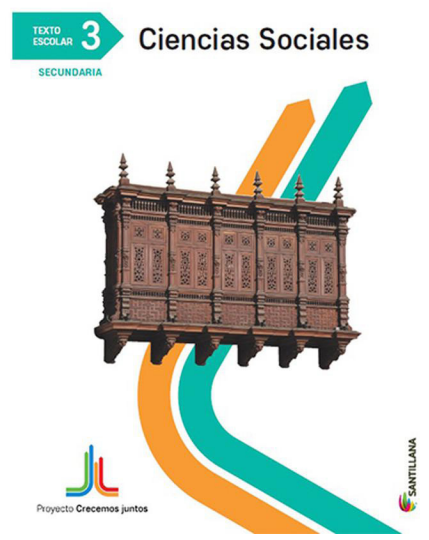

Figura 7. Portada del libro Ciencias Sociales 3 de la Editorial Santillana (2020)

Un detalle en torno al libro de la Editorial Santillana es que presenta como carátula solo un balcón republicano. Imagen sobria y despersonalizada, la cual no guarda mucha relación con las abundantes imágenes e ilustraciones históricas que integran el manual. Cabe destacar que la famosa editorial trabaja con bancos de imágenes, las cuales ofrecen múltiples opciones. El libro de Santillana alterna imágenes clásicas como cuadros (destacando los óleos y retratos de época), con distintas ilustraciones modernas y fotos de espacios históricos. Las portadas de los textos de historia suelen apelar a algún motivo patriótico (personajes ilustres, símbolos nacionales, mapa del país, etc.), pero en este caso Santillana nos presenta un símbolo cultural peruano, aunque principalmente limeño.

El libro de Santillana se estructura bajo una explicación general (o narrativa maestra), acompañada por numerosos documentos para profundizar (fragmentos de fuentes primarias y secundarias), además de cuadros de ampliación de algún tema y numerosas imágenes (mapas, cuadros, retratos, fotografías, etc.). Las fuentes anexadas y su análisis-evaluación correspondiente por los 
estudiantes cumplirían la función de generar una reflexión crítica de tipo histórica. El manual se limita a un discurso académico neutro, que toma distancia de cualquier enjuiciamiento histórico de alguna etapa o personaje. Así, por ejemplo, respecto a la famosa proclamación del 28 de julio de 1821 , el texto escolar se limita a decir:

[...] la crítica situación del bando realista obligó al virrey a abandonar la capital en julio de 1821 y trasladarse al Cusco. San Martín ingresó a Lima, donde el 28 de julio proclamó la independencia del Perú. Días antes de la proclamación, convocó al cabildo limeño para que se pronunciase a favor o en contra de esta. La sesión pública del cabildo se llevó a cabo el domingo 15 de julio de 1821, en que los asistentes votaron a favor de ella y firmaron el Acta de la Independencia. En ella se manifestaba «que la voluntad general está decidida por la independencia del Perú de la dominación española y de cualquier otra extranjera» (Santillana 2020, 101; los énfasis son nuestros).

El texto prescinde de alguna reflexión sobre el significado o la importancia de la proclamación de la independencia. Aunque la centralidad de este hecho ha sido cuestionada en los últimos años, no deja ser un momento clave de la historia nacional. El discurso histórico académico o formal demuestra sus límites, no solo en lo que enuncia, sino en lo que no enuncia (presencias y ausencias). El libro de actividades buscará cubrir este vacío con la pregunta: ¿cuál es el significado histórico de la proclamación de la independencia del Perú? (Santillana 2020, 77). Los estudiantes asumen la responsabilidad de generar una interpretación histórica sobre el tema, lo que en principio es adecuado, pero que no exime la necesidad de la inclusión de reflexiones mayores en el texto central. La experiencia directa en aulas demuestra que la pregunta formulada a los estudiantes se suele responder superficialmente o simplemente es omitida.

El análisis del contenido del texto de Santillana permite observar el desarrollo mayor o menor de ciertos hechos o sucesos, algo común en muchos manuales escolares. Así, por ejemplo, las batallas de Junín y Ayacucho son descritas en los siguientes términos:

En junio de 1824, Bolívar ordenó el desplazamiento de su ejército hacia la sierra central para sorprender al ejército realista del valle del Mantaro que estaba bajo el mando del general José de Canterac. Ambas fuerzas se enfrentaron en una 
batalla a orillas del lago Junín el 6 de agosto de ese año. La victoria de los patriotas se logró gracias al oportuno ataque del escuadrón Húsares del Perú, bautizado desde entonces como Húsares de Junín [...]. Luego de la derrota en Junín, el virrey La Serna decidió comandar directamente su ejército y marchó hacia Ayacucho. Bolívar, quien se encontraba enfermo, regresó a Lima y dejó a Sucre al mando. Ambos ejércitos se enfrentaron en una batalla en las pampas de Ayacucho el 9 de diciembre de 1824. La estrategia que utilizó Sucre le permitió al ejército patriota obtener un triunfo contundente y definitivo (Santillana 2020, 103-104; los énfasis son nuestros).

Dos eventos militares, tradicionalmente descritos con detenimiento por autores como Pons Muzzo, son presentados muy sintéticamente en el manual de historia de Santillana. Sin embargo, nuevamente los documentos para profundizar y el libro de actividades son los elementos diferenciadores, en la medida que incorpora fuentes primarias (parte de guerra escrito por el general Sucre) y fuentes secundarias, como textos dedicados a las guerrillas indígenas o el rol de las mujeres en la Independencia. Un texto de particular interés es el titulado «Los indígenas y los criollos ante la Independencia» del Nelson Manrique (libro de actividades), quien sostiene la tesis de la independencia como revolución política, pero no social, pues no buscaba cambios sociales, sino el traslado del poder colonial a los grupos criollos (Santillana 2020, 82).

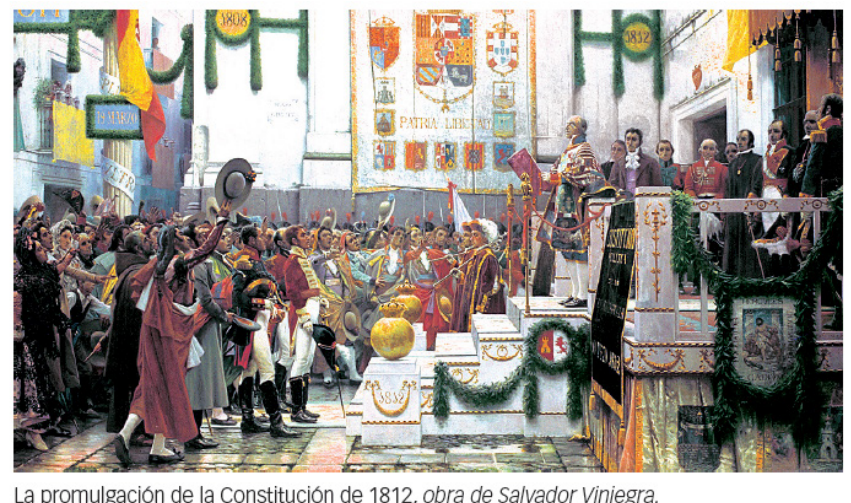

Figura 8. La promulgación de la Constitución de 1812, obra de Salvador Viniegra Fuente: Editorial Santillana $(2020,83)$

El discurso histórico presente en el manual escolar de Santillana se caracteriza, también, por la renovación temática. Se incorporan aspectos de his- 
toria social y cultural, o enfoques de historia local y de género. Es visible la revalorización de la participación popular en la lucha por la independencia (guerrillas indígenas y rebeliones previas), así como la participación de la mujer en el proceso de lucha independentista. Por ejemplo, a través de la visibilización de las hermanas Toledo, heroínas de la lucha y resistencia desde la sierra central (figura 9). A ello se suma, el espacio dedicado a la historia de la formación de los Estado latinoamericanos, buscando así una visión integral y comparativa del surgimiento de las nuevas repúblicas.

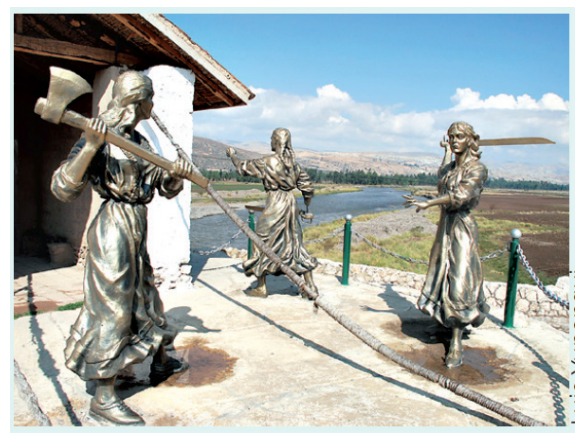

Figura 9. Las hermanas Toledo. Heroínas de la independencia (foto Luis Yupanqui). Fuente: Editorial Santillana $(2020,102)$

Finalmente, los textos de editorial de Santillana incorporan secciones denominadas «Aprendemos a ser ciudadanos», en los cuales se relaciona los temas históricos a temáticas de derechos ciudadanos, o se promueve reflexiones sobre la realidad actual del país. La incorporación de fragmentos de textos de numerosos historiadores reconocidos (Carlos Contreras, Antonio Zapata, Nelson Manrique, Alicia del Águila, José Luis Rénique, Marcos Cueto, Peter Klarén, etc.) asegura en parte la calidad del manual. Existen cambios y continuidades en los textos escolares, por ejemplo, en las representaciones gráficas. Las imágenes del libro de Santillana visibilizan cada vez más a los grupos subalternos, aunque persiste cierta tendencia a la representación individual o elitista. La historia, aunque proceso esencialmente colectivo, no se ve reflejada así en las ilustraciones de muchos textos escolares. ${ }^{10}$

10 Recientemente, en el conversatorio «Mujeres e independencia» (13 de septiembre del 2021), en el cual participaron las historiadoras Cecilia Méndez, Carlota Casalino, Christine Hunefeldt y la curadora de arte Karen Bernedo, la primera señala cómo en las representaciones a través de estatuas predomina la figura masculina, pero además individual, como si los procesos históricos no fueran colectivos. 
El mayor valor del texto de Santillana está en la concreción de los diversos ejercicios que propone a través de su libro de actividades. La no profundización en las diferentes fuentes que se presentan solo brindaría un texto informativo y explicativo, pero limitado por una narración neutra o aséptica. Esto último es un tema de debate, en la medida que en la producción académicahistoriográfica existe, por un lado, un afán de neutralidad y, por otro, la opción de toma de una posición más crítica frente al tema de estudio. Pablo Macera apuesta por esta segunda opción, pero ciertamente resultan discutibles algunas de sus posiciones. La ventaja es quizás que resulta más movilizador a nivel escolar, en la medida que cuestiona narrativas fuertemente instaladas. El análisis de las fuentes que emplean los libros escolares son también reveladoras; así, mientras en el libro de Macera se observa una bibliografía que incluye al historiador marxista Eric Hobsbawm, e historiadores marcadamente críticos como Heraclio Bonilla y Virgilio Roel Pineda, en el libro de Santillana las referencias bibliográficas son mayores, hallándose también historiadores más conservadores, como José de la Puente Candamo o Rafael Sánchez-Concha.

\section{Conclusiones}

Los estudios en torno a los manuales escolares de historia peruana han aumentado en las últimas décadas, desde el pionero La historia del Perú en los textos escolares (1989) de Gonzalo Portocarrero, se suman trabajos como los de José Chaupis y Daniel Parodi sobre los manuales escolares y la guerra del Pacífico (2019), o el de Antonio Espinoza sobre los textos de historia del Perú en el siglo XIX (2012). Los textos escolares de historia de mediados del siglo $\mathrm{XX}$ se caracterizaron por presentar el discurso histórico nacional criollo expresado en manuales como el de Gustavo Pons Muzzo. Este discurso oficial será cuestionado sobre todo en las décadas de los setenta y ochenta, época en que surge un discurso histórico nacional crítico que tendrá como uno de sus exponentes a Pablo Macera. La «ideología del mestizaje», propio de la historiografía conservadora o «peruanista» (Riva Agüero, Porras Barrenechea, De la Puente Candamo), convive con un discurso reivindicador de la identidad andina e indígena (Pablo Macera, Roel Pineda, Juan José Vega). A inicios del siglo XXI, se ha consolidado un discurso histórico academicista, que es incorporado por los textos de historia de editoriales como Santillana. Este discurso busca una aproximación menos nacionalista o ideologizada hacia el estudio 
de la historia. Incorpora temáticas de historia social y cultural, como historia de las mujeres e historia regional o local. El relato histórico en estos textos es aparentemente neutro, aséptico o imparcial. Ello contrasta con algunas interpretaciones marcadamente críticas como las propuestas por Pablo Macera. Aunque el discurso del mestizaje ha sido puesto en cuestión, no ha desaparecido y convive con el «discurso de la diversidad» (social, cultural). Una diversidad que no deja de tener en el centro a la cultura criolla-mestiza, castellana y occidentalizante. Los libros escolares, en tanto productos o artefactos destinados históricamente a legitimar al Estado, no podrían cuestionar las estructuras de este. No extraña que la crítica a los fundamentos de la desigualdad o la injusticia social sea solo mesurada en los actuales textos escolares. El discurso oficial, difundido desde los textos escolares, complementa al discurso oficial del calendario cívico-escolar o las ceremonias religiosas-civiles. La formación escolar se desarrolla entre estos discursos, de tono casi siempre conservador. Como último apunte, se debe destacar que los avances de los libros escolares tienen hoy, como reto, superar barreras como las limitaciones de tiempo para el desarrollo de contenidos, e incluso los pobres resultados de los estudiantes de secundaria en comprensión lectora. Hace algunos años, Natalia González (2010) reflexionaba al respecto: «Pocas horas de clase, textos que no incorporan los hallazgos académicos y una visión centralista que deja de lado al grupo mayoritario de nuestra población configuran en el aula una situación bastante sombría cuando observamos lo que en ella discurre». Suscribimos su opinión, aunque la incorporación de hallazgos académicos haya avanzado, en parte, con los textos de editoriales como Santillana. 


\section{Referencias bibliográficas}

Burga, M. 2005. La historia y los historiadores en el Perú. Lima: Fondo Editorial de la Universidad Nacional Mayor de San Marcos.

Carretero, M. 2005. Construir y enseñar. Las ciencias sociales y la historia. Buenos Aires: Aique.

Carretero, M. (Comp.). 2006. Enseñanza de la historia y memoria colectiva. Buenos Aires: Paidós.

Carretero, M. 2007. Documentos de Identidad. La construcción de la memoria histórica en un mundo global. Buenos Aires: Paidós.

Carretero, M. y Voss, J. (Comps.). 2004. Aprender y pensar la historia. Buenos Aires: Amorrortu Editores.

Chaupis, J. y Parodi, D. 2019. Lo que decimos de ellos. La guerra del Pacifico en la historiografía y manuales escolares peruanos. Lima: Universidad de Lima, Universidad Bernardo O'Higgins.

Chávez, T. 2006. La enseñanza de la historia del Perú en la enseñanza secundaria durante la segunda mitad del siglo XX. Lima: Fondo Editorial de la Pontificia Universidad Católica del Perú.

Cuenca, R. (Edit.). 2013. Cambio, continuidad y búsqueda de consenso, 1980-2011. Lima: Colección Pensamiento Educativo Peruano. Derrama Magisterial.

Eguren, M., De Belaunde, C. y González, N. 2005. Recursos desarticulados. El uso de textos en la escuela pública. Lima: Instituto de Estudios Peruanos.

Eguren, M. et al. 2005. Recursos desarticulados. El uso de textos en la escuela pública. Lima: Instituto de Estudios Peruanos.

Espinoza, A. 2012. La independencia en los textos escolares peruanos, 1821-c. 1921. En McEvoy, C. et al. (Edits.). En el nudo del imperio. Independencia y democracia en el Perú. Lima: Instituto de Estudios Peruanos, Instituto Francés de Estudios Andinos.

Ferro, M. 1990. Como se cuenta la historia a los niños en el mundo entero. Ciudad de México: Fondo de Cultura Económica.

González, N. 2010. La Independencia en los textos escolares. Argumentos, 4. https://cutt. ly/1UOIZPR

González Prada, M. 1908. Horas de lucha. Lima: Tip. «El progreso literario».

Ibagón, N. 2014. Los textos escolares y la enseñanza de la historia: elementos teóricos para entender su relación. Revista Hojas y Hablas, 11, 37-46.

Israel, C. 2009. Formación de valores a través de textos escolares en la Guerra del Pacífico. Desde el Sur, 1(1), 15-30. https://cutt.ly/TUOILuV 
López, A. y Carretero, M. 2004. La enseñanza de la historia mediante los libros de texto: ¿se les enseña la misma historia a los alumnos mexicanos que a los españoles? En Carretero, M. y Voss, J. (Coords.). Aprender y pensar la historia. Madrid: Amorrortu Editores.

Macera, P. 1978. Visión histórica del Perú (Del paleolitico al proceso de 1968). Lima: Editorial Milla Batres.

Macera, P. 1986. Historia del Perú. Independencia y república. Lima: Editorial Bruño.

Méndez, C. 2014 (7-8 de agosto). Presentación. Coloquio Internacional «Las Independencias antes de la Independencia». Lima. https://cutt.ly/8UOIO0U

MINEDU. 2020. Currículo Nacional de la Educación Básica. Lima: Ministerio de Educación. https://cutt.ly/GUOITSM

Miralles, P. y Gómez, C. 2017. Enseñanza de la historia, análisis de libros de texto y construcción de identidades colectivas. Historia y Memoria de la Educación, 6, 9-28. https://cutt.ly/GUOINee

Parodi, D. 2019. Nación contra nación: la relación con Chile en los manuales escolares peruanos (1975-2016). En Chaupis, J. y Parodi, D. 2019. Lo que decimos de ellos. La guerra del Pacífico en la historiografia y manuales escolares peruanos. Lima: Universidad de Lima, Universidad Bernardo O’Higgins.

Pons Muzzo, G. 1957. Historia del Perú. Época de la Emancipación. Lima: Librería El Inca.

Portocarrero, G. 1989. La historia del Perú en los textos escolares. En Oliart, P. y Portocarrero, G. El Perú desde la escuela. Lima: Instituto de Apoyo Agrario.

Prats, J. 2001. Enseñar Historia. Notas para una didáctica renovadora. Mérida: Junta de Extremadura. Consejería de Educación, Ciencia y Tecnología.

Ramírez, T. 2003. El texto escolar: una línea de investigación en educación. Revista de Pedagogía, 24(70), 273-292. https://cutt.ly/zUOIWSD

Romero, E. 2021. Visiones y discursos sobre el mestizaje en la historia y la historiografía peruana. Escripta, 3(5), 8-42. https://cutt.ly/YUOInoD

Santillana 2020. Ciencias Sociales 3. Lima: Editorial Santillana.

Tanaka, M. (Ed.). 2016. Antología del pensamiento crítico peruano contemporáneo. Buenos Aires: CLACSO. https://cutt.ly/rUOIx26

Van Dijk, T. 2009. Discurso y poder. Barcelona: Editorial Gedisa.

Vom Hau, M. 2009. Analizando la escuela: nacionalismo y educación en México, la Argentina y Perú. Papeles de trabajo, 3(5). https://cutt.ly/eUOIl32 